Trabalho, política e experiências indígenas 



\title{
Escravidão indígena e trabalho compulsório no Rio de Janeiro colonial $^{*}$
}

\section{Maria Regina Celestino de Almeida**}

-Resumo: Este artigo sublinha a importância da força de trabalho indígena na capitania do Rio de Janeiro até, pelo menos, meados do século XVII, enfocando a escravidão indígena e o trabalho compulsório dos aldeados. Embora o tráfico negreiro já estivesse, então, em franco desenvolvimento e o trabalho dos escravos negros já fosse também bastante utilizado, os índios constituíam, ali, mão de obra essencial.

Palavras chave: Escravidão indígena, trabalho compulsório, Rio de Janeiro

\begin{abstract}
This article emphasizes the importance of the indigenous labor force in the captaincy of Rio de Janeiro until at least the mid-seventeenth century, focusing on indigenous slavery Indian compulsory labor). Although the slave trade was already developing and the work of black slaves were already well used, the Indians constituted essential work force.
\end{abstract}

Keywords: Indian slavery; compulsory labor; Rio de Janeiro

A dinâmica da colonização da América portuguesa e espanhola dependeu em grande parte das populações indígenas, conforme vem sendo demonstrado por pesquisas recentes em diversas regiões. O Rio de Janei-ro não fugiu a regra: do século XVI ao XIX, as populações indígenas integraram a força de trabalho da capitania. Essa integração variou, ao longo do tempo, quanto às diferentes atividades exercidas pelos índios e, principalmente, quanto à sua intensidade. Enfocando o trabalho compulsório dos índios aldeados e a escravidão indígena, o objetivo deste artigo é sublinhar a importância da mão de obra indígena na capitania do Rio de Janeiro. Embora o tráfico negreiro já estivesse em franco desenvolvimento e o trabalho dos escravos negros já fosse também bastante utilizado, até pelo menos meados do século XVII, os índios constituíam, ali, força de trabalho essencial.

* Este artigo revisa e amplia questões discutidas no artigo "Considerações sobre a Presença Indígena na Economia do Rio de Janeiro Colonial”, Cativeir o e Liberdade. Revista Interdisciplinar em História Social. UFRJ/UFF. Ano II, vol.4, 1997, pp. 46-58. Ambos constituem parte de minha tese de doutorado publicada com o título Metamorfoses Indígenas: identidade e cultura nas aldeias coloniais do Rio de Janeiro. Rio de Janeiro, Arquivo Nacional, 2003.

** Departamento de História/UFF, reginacelestino@uol.com.br. 
A utilização dos escravos africanos como força de trabalho aumentava na medida em que diminuiam as possibilidades de uso da mão de obra indígena, conforme demonstraram Stuart Schwartz, na Bahia, e John Monteiro, em São Paulo. ${ }^{1}$ Parece lícito supor que o mesmo ocorreu no Rio de Janeiro, onde, até meados do seiscentos, a utilização da força de trabalho indígena ainda era amplamente empregada. É possível observar, ali, algumas características típicas das regiões consideradas periféricas, no que diz respeito à reprodução parcialmente endógena da força de trabalho. Apesar da escassez de fontes para se identificar a presença de escravos índios no Rio de Janeiro colonial, dadas as restrições legislativas, é possível encontrar, nos documentos, claros indícios de sua existência significativa até, pelo menos, a segunda metade do século XVII.

Cabe lembrar que a política indigenista da Coroa portuguesa, sempre oscilante entre a necessidade de incluir os índios como força de trabalho e tê-los como aliados nas aldeias coloniais, caraterizou-se por uma infinidade de leis que se sucediam e, por vezes, se anulavam. ${ }^{2} \mathrm{O}$ estabelecimento dessas leis e seu cumprimento se faziam conforme as pressões dos grupos interessados: autoridades locais e metropolitanas, colonos, jesuítas e os próprios índios. Sem detalhar essa problemática, cabe lembrar que até 1755, quando, no âmbito das reformas pombalinas, proibiu-se definitivamente a escravidão indígena, ${ }^{3}$ prevaleceu na colônia duas possibilidades legítimas de escravização indígena: o resgate e a guerra justa. A primeira consistia em trocar, com os grupos aliados, seus prisioneiros de guerra que, resgatados pelos portugueses, podiam se tornar escravos. A guerra justa, por sua vez, justificava a escravização de povos que não colaboravam com os portugueses. Ambas foram objeto de discussões e legislações infindáveis que não serão aqui abordadas. ${ }^{4}$

\section{Escravidão indígena e escravidão africana: algumas reflexões}

A ampla utilização da mão de obra indígena constituía a alternativa mais racional numa economia que visava à acumulação com um mínimo de investimentos de capitais. Capitais raros, deve-se lembrar, para colonos europeus que vinham à América em busca de um enriquecimento impossível de ser alcançado nos seus reinos. A guerra, principalmente contra o gentio, apresentava-se, na América, como mecanismo fundamental de montagem da economia colonial, como observou João Fragoso. ${ }^{5}$

1 SCHWARTZ, Stuart. Segredos Internos: engenhos e escravos na sociedade colonial. Trad. Laura Teixeira Motta. São Paulo: Companhia das Letras, 1988; MONTEIRO, John. Negros da Terra: índios e Bandeirantes nas Origens de São Paulo. São Paulo: Companhia das Letras, 1994.

2 Sobre a legislação indigenista da Coroa portuguesa ver PERRONE-MOISÉS, Beatriz. "Índios livres e índios escravos: os princípios da legislação indigenista do período colonial (séculos XVI a XVIII)". In: CUNHA, M. Carneiro da. História dos Índios no Brasil. São Paulo: Companhia das Letras, 1992, p. 115-132; BEOzZO, José Oscar. Leis e Regimentos das Missões: política indigenista no Brasil. São Paulo: Loyola, 1983.

3 "Lei de 6 de junho de 1755. Restitui aos índios do Grão-Pará e Maranhão a liberdade de suas pessoas, bens e comércio na forma que nella se declara". NAUAD, Leda Maria Cardoso. "Documentos sobre o índio brasileiro", (2 $2^{\mathrm{a}}$ parte), Revista de Informação Legislativa, v. 8, n. 29, 1971, pp. 261-262, apud PERRONE-MOISES, Beatriz. "Índios livres e índios escravos", p. 587. Convém lembrar que a escravidão indígena foi oficialmente retomada quando, em 1808, D. João VI declarou guerra justa aos botocudos e, posteriormente, aos kaingangs. Sobre isso ver CUNHA, Manuela Carneiro da. Legislação Indigenista no Século XIX: uma compilação (1808-1889). São Paulo: EDUSP, 1992.

4 Sobre isso, ver PERRONE-MOISES, “Índios livres e índios escravos".

5 FRAGOSO, João L. R. "À espera das frotas: hierarquia social e formas de acumulação no Rio de Janeiro, 
Isso é claramente observável no Rio de Janeiro, cujas condições específicas de criação da cidade e ocupação da região fez-se a partir da guerra de conquista envolvendo inúmeros povos indígenas na condição de aliados ou de inimigos. Ambos desempenharam importante papel, tanto na guerra como na construção e desenvolvimento da nascente capitania: os inimigos tornavam-se escravos legítimos e eram dados como recompensa aos bravos guerreiros do rei. Os aliados aldeavam-se para cumprir inúmeras funções dentre as quais a de servir ao rei, aos moradores e aos missionários sob a imposição do trabalho compulsório, regulado por várias leis que, como de praxe, variavam ao longo do tempo.

Os povos indígenas, no entanto, não estavam à disposição dos europeus e sua incorporação ao mercado de trabalho na capitania - como aldeados ou como escravos - fez-se através da legislação e de muitas disputas cotidianas. A documentação sobre conflitos em relação ao trabalho dos índios evidencia que as aldeias não existiam simplesmente para satisfazer os interesses dos colonos e da Coroa como redutos de mão de obra. O cumprimento ou não das resoluções do rei na colônia dependia do jogo de forças entre os agentes sociais envolvidos e, de ambos os lados, houve casos de desobediência às ordens da Coroa. A inserção dos índios nas atividades produtivas da capitania passava também por seus próprios interesses e possibilidades de barganha ou resistência. Apesar da condição subalterna e dos incalculáveis prejuízos, abusos e explorações que lhes eram impostos, as disputas não se faziam à sua revelia, como costumava ser sugerido pela historiografia. De acordo com a documentação, os índios participavam dos conflitos em torno de seu trabalho, como se verá mais adiante. ${ }^{6}$

João Fragoso, ao analisar as formas de acumulação da elite no Rio de Janeiro do século XVII, apontou para sua falta de liquidez, caracterizando uma economia com baixa taxa de acumulação e mercado precário, cuja reprodução se fazia através de contínuo e crônico endividamento.7 A montagem das fortunas das famílias mais poderosas da região, isto é, daquelas ligadas ao poder com alianças importantes e que deram origem a outras famílias senhoriais não se deu, segundo o autor, apenas através de compras. Acurada análise dos livros de escrituras públicas, levou João Fragoso a concluir que estes homens não adquiriam a força de trabalho necessária para mover suas atividades econômicas apenas no mercado de escravos. Seu patrimônio agrário escravista constituiu-se e reproduziu-se pela doação de sesmarias, índios cativos e crédito, aos quais tinham acesso exatamente por suas estreitas relações com o poder, o que Ihes conferia a possibilidade de ocupar importantes cargos de comando na colônia. ${ }^{8}$ Estes parecem ter sido fundamentais para garantir o direito de obter terras e homens que, somados ao crédito, constituíam a base das fortunas senhoriais no Rio de Janeiro do século XVII. Reafirmo, portanto, a importância da guerra, principalmente daquela contra o gentio pela conquista de novos espaços coloniais que aparecia, conforme expressão de Fragoso, como um dos mecanismos fundamentais na formação do processo produtivo colonial.

Embora a prática de escravizar índios ou de mantê-los sob administração particular, não fosse tão frequente e visível na capitania do Rio de Janeiro como

século XVII". Cadernos do laboratório Interdisciplinar de Pesquisa em História Social. Rio de Janeiro: IFCS/ UFRJ,n. 1, 1995, pp. 53-62.

6 ALMEIDA, M. Regina Celestino de. Metamorfoses indígenas: identidade e cultura nas aldeias coloniais do Rio de Janeiro. Rio de Janeiro: Arquivo Nacional, 2003.

7 FRAGOSO. "À espera das frotas".

8 FRAGOSO, João. "Cartas que falam sobre a pintura do architeto do mundo". Documentos Históricos. Rio de Janeiro: Biblioteca Nacional do Rio de Janeiro, v. CXI, 1997. 
na de São Paulo, ${ }^{9}$ não faltam indícios de sua ocorrência em considerável escala, sobretudo no século XVII. É instigante observar que ela não se restringia aos colonos pobres. Os beneditinos e D. Vitória de Sá constituíam alguns dos destacados personagens do Rio de Janeiro que tinham índios administrados e os deixavam em testamento. Em 1705, uma petição de Dom Abade e dos demais religiosos do Convento de São Bento solicitava a manutenção dos índios administrados em suas fazendas sob sua proteção e tutela, informando que estes lhes haviam chegado por provisões, despachos e testamentos "...e dos quais têm sido tutores, curadores e administradores de todos que em todas as fazendas tiveram e os foram instruindo, doutrinando e administrando". ${ }^{10}$

Os termos utilizados para definir suas relações com os índios e sobretudo o fato de alguns lhes terem chegado através de testamentos são reveladores de uma situação muito semelhante à administração particular exercida pelos paulistas que caracterizava uma forma de escravidão disfarçada, como demonstrou John Monteiro. ${ }^{11} \mathrm{O}$ direito a herdar índios administrados e de manter a administração sobre seus descendentes foi amplamente utilizado em São Paulo e a mesma concepção surge claramente na súplica dos beneditinos a Vossa Majestade para que

Ihes mande passar Provisão para que na mesma conformidade daqui em diante os governe e administrem, ficando sempre debaixo de sua proteção e tutela todos e quaisquer que em seu poder nascerão e se criarão, e que dos ditos tiverem descendido e descenderem ou por qualquer via ao seu poder vierem ... ${ }^{12}$

Sobre o mesmo assunto, convém citar ainda o testamento de D. Vitória de Sá, neta de Salvador Correa de Sá e viúva de Dom Luiz de Cespedes, que fora governador geral do Paraguai. Essa senhora de famíla proeminente na capitania, embora não tenha utilizado a expressão administrado em seu testamento, feito aliás em favor dos beneditinos, inclui entre seus bens "alguma gente da terra, todos de meu serviço e obrigados". ${ }^{13}$

Alguns documentos tratam especificamente da escravização dos índios, grosso modo, proibindo-a, porém explicitando sua existência. Carta régia de 1706 mandava retirar os índios cativos das fazendas de São Bento e providenciar seu aldeamento. ${ }^{14}$ Especialmente revelador a esse respeito é o testamento do Capitão Miguel Riscado, um dos sete capitães dos Campos dos Goitacazes que, em 1648, declarava em testamento possuir "[...]cinquenta peças do gentio da terra Carijos [...]" e apenas quinze da Guiné. ${ }^{15}$

9 Sobre os índios administrados em São Paulo, ver MONTEIRO. Negros da Terra.

10 Carta Regia mandando informar uma petição por cópia, do Dom Abade e mais religiosos do Convento de São Bento da Cidade do Rio de Janeiro, acerca da Administração dos Indios, que assistiam nas suas fazendas. 11 de maio de 1705. Ms. Arquivo Nacional (AN) Cod. 952; vol. 15; fls. 302-305.

11 MONTEIRO. Negros da Terra.

12 Carta Regia mandando informar uma petição por cópia, do Dom Abade e mais religiosos do Convento de São Bento da Cidade do Rio de Janeiro, acerca da Administração dos Indios, que assistiam nas suas Fazendas. 11 de maio de 1705. Ms. AN Cod. 952; vol. 15; fls. 302-305.

13 Testamento de D. Vitoria de Sá, 30 de janeiro de 1667 In: SILVA-NIGRI, Dom Clemente Maria da. Construtores e artistas do Mosteiro de São Bento do Rio de Janeiro. Salvador: Tipografia Beneditina, 1950, p. 249.

14 Carta Régia a D. Fernando Martins Mascarenhas de Lencastro, mandando retirar os índios cativos nas fazendas dos religiosos de São Bento, e providenciar o seu aldeamento. Lisboa, 12 de junho de 1706. Ms. Biblioteca Nacional (BN) II- 34, 23,1 $\mathrm{n}^{\circ} 55$.

15 Testamento do Capitão Miguel Riscado, um dos sete Capitães dos Campos dos Goitacá, 17 de janeiro de 1648, apud SILVA-NIGRI. Construtores e artistas do Mosteiro de São Bento do Rio de Janeiro, p. 242. 
Indícios menos explícitos sobre a escravização ou administração particular dos índios aparecem nas referências a grupos de defesa pessoal ou espécie de exércitos particulares formados por índios que, além da segurança, proporcionavam status aos seus proprietários e/ou administradores. Os documentos falam dos moradores com "seus índios", indicando senão propriedade, pelos menos um estrito controle sobre eles. Em 1693, o provedor da Fazenda, ao defender a ideia de priorizar o desenvolvimento agrícola sobra a exploração das minas, dizia que, por serem ambiciosos, os homens ao perceberem os benefícios maiores da cultura em relação às conquistas do sertão, "[... ] logo farão que seus Índios troquem as flechas pelos arados [...]". ${ }^{16}$ Em 1699, o governador Arthur Sá e Menezes ordenou aos moradores com índios em suas casas ou fazendas que os armassem com arcos e flechas para acompanhá-lo ao Sertão. ${ }^{17}$ No início do século XVIII, o Desembargador Antonio da Cunha Soutomaior narrava um episódio de delinquência ocorrido no recôncavo no qual "[... ] um Luiz Barbalho e um filho lavrador de açúcar fora com quantidade de negros, mulatos e índios ao engenho de Salvador Pinto para matar um seu filho[... ]". ${ }^{18}$

Mais revelador a este respeito, no entanto, é o caso narrado pelo governador do Rio de Janeiro, Francisco de Soutomaior (1644-1645), que explicita o controle direto dos índios da aldeia de Mangaratiba pela família Sá, acusada de incentivá-los a rebelar-se contra as ordens do poder público. Em 1645, referindose à aldeia que fora instalada por Martim de Sá, Soutomaior dizia terem os índios dali aos poucos desertado, "[... ] vindo a ficar os mais destes em fazendas e engenhos do dito Martim de Sá". ${ }^{19}$

Essa aldeia fora estabelecida pelo próprio Martim de Sá que trouxera índios tupiniquins de Porto Seguro e os estabelecera em suas terras. Governador do Rio de Janeiro por duas vezes (1602-1608;1623-1632), Martim de Sá era conhecido apresador de índios e tentara em vão obter a administração particular dos índios dessa aldeia que, no entanto, lhe foi negada. A política indigenista da Coroa, cabe lembrar, incentivava os descimentos e o estabelecimento de aldeias por particulares, mas, em geral, proibia a administração particular, como no caso aqui citado. Na prática, porém, a proibição parece não ter se cumprido, ao menos nessa aldeia de Mangaratiba, como revela o seguinte episódio narrado pelo governador Soutomaior.

Segundo ele, tendo ordenado ao Principal da aldeia que lhe fornecesse índios de sua jurisdição, respondeu-Ihe este, por influência de D. Catarina Ugarte (mulher de Salvador Correa de Sá e Benevides), "[... ] que não conhecia nem obedecia senão ao general Salvador Correia de Sá". ${ }^{20}$ Ao tentar prendê-lo, enviando soldados ao engenho de D. Catarina, onde o índio se refugiara, foram eles recebidos a tiros por ordem da poderosa senhora. Parece um caso típico de administração particular sobre a aldeia, cujo estabelecimento se fizera com a recomendação de que seu fundador não teria administração temporal sobre ela. Isso provavelmente não se cumpriu.

16 Parecer do Provedor da Fazenda sobre os inconvenientes das minas do Brasil. 8 de janeiro de 1693. Ms. Arquivo Histórico Ultramarino (AHU) Documentos Avulsos Rio de Janeiro (RJA) cx.6, doc.2.

17 "Ordem sobre os moradores aparelharem os seus índios com arcos e flechas para acompanharem 0 Governador ao Sertão" Rio de Janeiro, 20 de junho de 1699. Ms. AN, cod.77, vol. 09, fl. 28.

18 Consulta do Conselho Ultramarino sobre um caso de delinquência na capitania do Rio de Janeiro a respeito do direito dos governadores decidirem sobre a questão da justiça. Lisboa, 24 de março de 1710. Ms. AHU. RJA, cx. 8, doc. 75 .

19 Carta do Governador Francisco Soutomaior. 1645. MS.AHU RJA, cx. 2, doc. 57.

20 Carta do Governador Francisco Soutomaior. 1645. MS.AHU RJA, cx. 2, doc. 57. 
Convém atentar também para a resposta do índio bastante sugestiva sobre uma relação clientelística entre eles, índios, e seus prováveis administradores da família Sá. A resposta sugere uma fidelidade em nível bastante pessoal, construída, com certeza, a partir de relações de mútua dependência e troca de favores de ambos os lados. Os índios dessa aldeia deviam ver nos Sá poderosos aliados e seus protetores no mundo colonial, onde habitavam. Afinal, eles Ihes haviam dado as terras e, com certeza, ainda lhes garantiam algumas vantagens, como por exemplo, a de não ter religiosos residentes em sua aldeia, o que provavelmente Ihes permitia viver em liberdade de costumes. $O$ episódio demonstra igualmente ter a família Sá zelado pelos seus compromissos com os índios, pois D. Catarina não titubeou em receber a tiros os soldados que vinham prender seu fiel principal.

Todos esses exemplos sugerem relações de controle dos moradores sobre os índios em suas casas, fazendas ou nas próprias aldeias, caracterizando uma situação de administrados ou de escravos. Outro episódio especialmente relevante para se pensar sobre a presença e a importância da mão de obra indígena no Rio de Janeiro, em meados do século XVII, ocorreu em 1640. Em reação ao decreto de Felipe III (IV da Espanha) que, além de proibir a escravização dos índios, exigia a libertação dos cativos, colocando-os sob a jurisdição dos inacianos, os moradores junto com a Câmara do Rio de Janeiro se insurgiram violentamente contra os jesuítas, mentores do citado decreto. ${ }^{21}$

Vivaldo Coaracy procurou justificar essa revolta, afirmando que esta lei desorganizava a economia da colônia, principalmente a das capitanias de São Vicente e Rio de Janeiro, onde a porcentagem de escravos africanos era mínima. ${ }^{22}$ Essa afirmativa somada ao episódio de insurreição dos colonos aponta para uma situação semelhante a de áreas periféricas, pois motins dessa envergadura contra os padres da Companhia de Jesus ocorreram no Pará, Maranhão e São Paulo. Não obstante, deve-se ressaltar que, no Rio de Janeiro, as consequências contra os padres foram suavizadas pela força maior dos jesuítas na capitania respaldados pelos governadores, sobretudo pela poderosa família Sá, representada naquele momento por Salvador Correa de Sá e Benevides. Essa ocorrência, a meu ver, reforça a ideia de que o Rio de Janeiro do século XVII apresentava características semelhantes a essas regiões quanto à reprodução parcialmente endógena de sua mão de obra.

Apesar da existência do mercado de escravos negros no Rio de Janeiro do século XVII, a demanda parece não ter sido suficiente para garantir um preço alto do africano, constantemente desviado para as capitanias do norte, onde alcançavam melhor preço. ${ }^{23} \mathrm{~A}$ frequência e gravidade desse procedimento podem ser avaliadas pela decisão de 1620 de que as "peças" trazidas de Angola para o Rio de Janeiro só pudessem ser dali exportadas para outras capitanias, com autorização especial da Câmara. ${ }^{24}$ Apesar da opinião de Coaracy, segundo o qual, isso confirma a existência de considerável tráfico negreiro no Rio de Janeiro, acredito, ao invés disso, estarmos diante de um fenômeno típico de áreas periféricas, onde a possibilidade de escravização do índio, muito mais barato do que o negro, limitava a demanda por escravos africanos, inibindo, consequentemente o desenvolvimento

21 COARACY, Vivaldo. O Rio de Janeiro no Século XVII. Rio de Janeiro: Livraria José Olympio Ed., 1965, pp. 98101. 
deste mercado. ${ }^{25}$ Baseado em dados de Perdigão Malheiros, o autor afirma que, no século XVII, o preço médio do escravo índio era de $4 \$ 000$ e o do africano era de $100 \$ 000 .{ }^{26}$

Alencastro destacou o papel do Rio de Janeiro como peça chave na integração do Atlântico sul, estabelecendo a ligação entre Angola e Buenos Aires, através do tráfico negreiro que, com muita frequência, desviava os escravos negros da capitania do Rio de Janeiro para outras regiões, sobretudo Buenos Aires. ${ }^{27}$ Cabe lembrar, com o mesmo autor, que Salvador de Sá e sua poderosa família tinham grande envolvimento com o contrabando no Rio da Prata, cuja mercadoria principal era o escravo negro, introduzido pelos portugueses em Buenos Aires em troca da tão cobiçada prata. Na década de quarenta do século XVII, a restauração monárquica portuguesa teve efeitos consideráveis sobre as relações luso-espanholas no sul da América, tendo significado para os colonos portugueses o fim do acesso fácil às riquezas do Rio da Prata e consequentemente desencadeado uma busca frenética por novas possibilidades de acesso às minas. Isso incluía o incremento do contrabando na região e a intensificação das expedições para o descobrimento de novas minas, o que implicava na necessidade de escravos negros e índios em larga escala. Os índios, além de serem imprescindíveis nas expedições ao sertão, constituíam, como visto, força de trabalho fundamental na capitania e sobretudo nessa época, quando os escravos negros escasseavam pela tomada de Angola pelos holandeses.

Quanto aos negros, convém lembrar que constituíam a principal mercadoria de contrabando no Rio da Prata e não resta dúvida, como demonstrou Alencastro, que a expedição de libertação de Angola organizada por Salvador Correa de Sá e Benevides, em 1648, visava sobretudo restabelecer a conexão atlântica ligando Angola a Buenos Aires, através do tráfico negreiro, via Rio de Janeiro. “'Negros': tal era a mercadoria que os castelhanos vinham buscar na Guanabara. Sem Angola ficava difícil relançar a carreira Rio-Buenos Aires". ${ }^{28}$ Pode-se deduzir daí que a mola mestra da reconquista de Angola não foi a demanda de escravos negros no Rio de Janeiro e sim a necessidade de recuperar, na África, o amplo acesso à principal mercadoria contrabandeada pelos portugueses no sul do Brasil: o escravo africano.

Há, sem dúvida, outras razões para justificar o caráter redistribuidor do tráfico no Rio e a baixa demanda local por escravos negros, destacando-se entre elas o fato de que, no século XVII, a proeminência da capitania advinha muito mais de suas funções políticas e comerciais do que produtivas. Aliás, como principal porto da região, o Rio manteria sempre essa função redistribuidora, mesmo no auge do desenvolvimento do tráfico, quando a demanda local já se tornara bastante intensa. ${ }^{29}$ Além disso, no início do século XVIII, os escravos africanos eram desviados para as minas em escala considerável, o que suscitou o estabelecimento de várias leis, procurando controlar a situação. É preciso, no entanto, considerar que, embora insignificantes no âmbito da colônia, as atividades produtivas do Rio no século

25 Situação semelhante pode ser observada na Amazônia colonial. Sobre isso ver ALMEIDA, M. Regina Celestino de. "Trabalho Compulsório na Amazônia: séculos XVII e XVIII”. Arrabaldes. Petrópolis, n.2, 1988, pp. 101-117.

26 COARACY. O Rio de Janeiro no Século XVII, p. 47.

27 ALENCASTRO, Luiz Felipe de. O trato dos viventes: formação do Brasil no Atlântico Sul. São Paulo: Companhia das Letras, 2000, pp. 222-224.

28 ALENCASTRO. $O$ trato dos viventes, p. 224.

29 FLORENTINO, Manolo Garcia. Em Costas Negras: uma História do tráfico atlântico de escravos entre a África e o Rio de Janeiro (séculos XVIII e XIX). Rio de Janeiro: Arquivo Nacional, 1995, p. 46. 
XVII não eram nada desprezíveis: havia cento e vinte engenhos no final do século e a produção de açúcar era bastante considerável nesse período..$^{30}$ Considerando as concepções hierárquicas dos colonos portugueses e suas ideias em relação ao trabalho e somando a isso, as amplas possibilidades de utilização da força de trabalho indígena, conforme evidências já apontadas, não há como negar a emergência dessa última como importante variável para inibir o crescimento da demanda local por africanos.

Se admitimos terem sido os índios tão importantes para a colonização, é forçoso concluir que sua alta mortalidade tenha provocado sérios efeitos sobre ela. Schwartz demonstrou que, na Bahia colonial, a utilização do escravo negro só se intensificou quando a mão de obra indígena já não era suficiente para suprir as necessidades da lavoura, por várias razões. Dentre elas, o autor destaca a recusa ao trabalho e a alta mortalidade. ${ }^{31}$ Fernão Cardim observou a decadência de São Vicente no final do século XVI por "[...] estarem as terras gastas e faltarem índios que as cultivem [...]". ${ }^{32}$ No Rio de Janeiro, conforme os argumentos aqui desenvolvidos, o mercado de escravos negros, apesar de existente no século XVII, parecia não dispor de uma clientela local expressiva, que iria se desenvolver consideravelmente no decorrer do século XVIII. Embora isso se justifique, grosso modo, pelo desenvolvimento da economia e incremento das atividades produtivas ao longo do Setecentos, não se pode esquecer a diminuição das possibilidades de aproveitamento da mão de obra indígena como mais uma importante variável.

No Rio de Janeiro, como em outras áreas da América, a mão de obra indígena foi utilizada tanto quanto possível, como alternativa para a exploração máxima de recursos com um mínimo de investimentos de capitais, escassos no Rio de Janeiro dos séculos XVI e XVII. O mercado de escravos negros, por sua vez, desenvolveuse, no momento em que a força de trabalho indígena, por várias razões, já não era mais suficiente para suprir as demandas das atividades produtivas em expansão. Discordo, portanto da ideia de alguns autores ${ }^{33}$ de que o tráfico negreiro foi introduzido para responder às necessidades de novos investimentos geradas pelo fluxo de capital advindo da economia mercantil. Ao invés disso, concordo com outros, tais como Ciro Cardoso, Jacob Gorender, ${ }^{34}$ e pelas evidências aqui relacionadas, que a escravidão negra se introduziu e se desenvolveu na América portuguesa para atender às exigências da produção colonial, cujos fatores incluem o esgotamento das amplas possibilidades de exploração da mão de obra indígena.

Dentre as razões para a diminuição do uso da força de trabalho indígena na capitania do Rio de Janeiro inclui-se, sem dúvida, a altíssima mortalidade causada pelas guerras e pelas frequentes epidemias que, sobretudo nos dois primeiros séculos da colonização, dizimavam os índios em larga escala, conforme testemunham as fontes. Alencastro ${ }^{35}$ argumentou que "[... ] a vulnerabillidade dos índios ao

30 FRAGOSO. “À espera das frotas", p. 53.

31 SCHWARTZ. Segredos Internos, pp. 46-56.

32 CARDIM, Fernão.Tratados da Terra e da Gente do Brasil. São Paulo-Belo Horizonte, EDUSP-Itatiaia: 1980. p. 174 .

33 NOVAIS, Fernando. Portugal e Brasil na crise do antigo sistema colonial (1777-1808). São Paulo: HUCITEC, 1979, pp. 92-105; NEME, Salete Maria Nascimento. A utilização da mão de obra indígena na região do Rio de Janeiro na segunda metade do século XVI. Dissertação de Mestrado, Universidade Federal Fluminense, Niterói, 1985, p. 153.

34 CARDOSO, Ciro Flamarion. "As concepções acerca do sistema econômico mundial: a preocupação obsessiva com a extração do excedente". in: LAPA, José do Amaral (org.) Modos de produção e realidade brasileira. Petrópolis: Vozes, 1980; GORENDER, Jacob. O escravismo colonial. São Paulo: Ed. Ática, 1978.

35 ALENCASTRO. O trato dos viventes, pp. 127-133. 
choque epidemiológico [... ] constituiu um fator restritivo à extensão do cativeiro indígena e, inversamente facilitou o incremento da escravidão negra". ${ }^{36}$ Os negros tinham maior resistência para algumas doenças, sobretudo as africanas, que periodicamente assolavam a colônia portuguesa (a ancilostomíase, a febre amarela e a malária falciparum). Por essa razão, deviam ser, segundo ele, economicamente preferíveis aos escravos índios. Estes, embora "[... ] mais baratos que os africanos acabavam saindo mais caros porque morriam em maior número [...]”, conforme observou Rocha Pitta, ${ }^{37}$ após uma epidemia de febre amarela em Pernambuco e na Bahia, nas duas últimas décadas do Seiscentos. A argumentação de Alencastro constitui um fator a mais para confirmar a ideia de que o desenvolvimento da demanda por escravos negros caminhou junto com a diminuição das possibilidades de utilização do trabalho indígena.

\section{Trabalho compulsório dos aldeados: disputas sobre repartição, serviços e salários}

Convém lembrar que, além dos escravos índios, os moradores contavam também com os índios aldeados que deviam igualmente servi-los. Seu emprego, no entanto, era mediado não apenas pela legislação, como também pelas disputas cotidianas na colônia em torno de sua repartição, serviços e salários. Eram disputas acirradas que evidenciam a importância do trabalho indígena na capitania e a participação e interesse dos próprios índios nesses conflitos. Se a situação de aldeados impunha aos índios várias obrigações, dava-lhes também alguns direitos que aprenderam a defender, conforme as novas práticas culturais e políticas por eles incorporadas no longo processo de metamorfoses étnicas e culturais vivenciado nas aldeias, em contatos intensos com os padres e demais agentes sociais. Agiram conforme a cultura política do Antigo Regime, baseada na troca de favores e serviços, num sistema de reciprocidade, através do qual os súditos serviam ao rei que, em seu papel de monarca justo e piedoso, os recompensava. As reivindicações dos aldeados, mais especificamente de suas lideranças, demonstram que eles incorporaram rapidamente essa prática. Apresentavam-se com o nome de batismo cristão, a partir da aldeia na qual habitavam, enfatizando, em geral, os muitos serviços prestados ao rei que os faziam merecedores das solicitações reivindicadas. ${ }^{38}$

Apesar dos imensos prejuízos impostos aos índios, as aldeias coloniais serviam também aos seus interesses. Índios, colonos, missionários e autoridades locais e metropolitanas disputavam, grosso modo, na justiça colonial para fazer valer suas diferentes expectativas em relação às aldeias, sobretudo por questões do trabalho indígena. A documentação sobre conflitos permite perceber que as aldeias tinham para eles diferentes significados e funções, os quais se alteravam, conforme a dinâmica da colonização e de suas relações. Se para a Coroa e missionários, elas deviam transformar os índios em súditos cristãos e força de trabalho para defender seus territórios e garantir o desenvolvimento das atividades produtivas, e para os colonos elas significavam, principalmente, redutos de mão de obra, os índios viam nelas, possibilidades de sobrevivência.

36 ALENCASTRO. O trato dos viventes, $\mathrm{p}, 127$.

37 ROCHA PITTA, Sebastião da. História da América portuguesa ([1730], São Paulo: 1976 p.181, apud ALENCASTRO. O trato dos viventes, p. 137.

38 ALMEIDA. Metamorfoses indígenas. 
Ao estabelecer acordos com os portugueses, em condições de extrema violência e desigualdade, os índios deviam buscar, principalmente terra e proteção, como informam os documentos. Diante do caos instalado nos sertões, com guerras, epidemias, escravizações em massa e redução, cada vez maior, de territórios livres e recursos naturais, o ingresso nas aldeias coloniais surgia, com certeza, como possibilidade de sobrevivência. Sujeitavam-se às regras portuguesas, passando a viver em condição subordinada e sujeitos ao trabalho compulsório. Misturavam-se com outros grupos étnicos e sociais, viam reduzir-se as terras às quais tinham acesso e expunham-se às altas mortalidades. Além de tudo, submetiam-se à nova rotina, que lhes proibia o uso de certas práticas culturais e os incentivava a abandonar antigos costumes e incorporar novos valores, como parte do processo de transformá-los em súditos cristãos. Apesar de tudo, não abdicaram de negociar sobre suas perdas como informam instigantes documentos sobre seus conflitos e reivindicações no interior das aldeias. Os variados registros sobre esses conflitos informam sobre suas principais solicitações na condição de aldeados e súditos cristãos do rei: queriam garantir suas terras, queriam cargos, aumentos de salários, ajudas de custo, destituição de autoridades não reconhecidas por eles e, principalmente, recusavam a escravidão.

Na rígida hierarquia social do Antigo Regime, os índios aldeados tinham um lugar jurídico próprio, ao qual correspondiam deveres e direitos específicos, embora ocupassem um dos estratos mais baixos da sociedade. Afinal, ser súdito cristão não significava absolutamente condição de igualdade com os demais. Eram submetidos ao trabalho compulsório e estavam sujeitos aos estatutos de limpeza de sangue que os discriminavam e os proibiam, até as reformas pombalinas, de ocupar determinados cargos e receber títulos honoríficos. Abaixo deles, no entanto, estavam os escravos índios e negros, bem como os "índios bravos" dos sertões, sempre passíveis de serem escravizados. Assim, apesar das condições limitadas e opressivas, os aldeamentos indígenas Ihes ofereciam algumas garantias, principalmente, se comparados com outros grupos etnicos e sociais que viviam em condições inferiores, tais como escravos negros e indígenas. Nas aldeias coloniais encontraram possibilidades de agir para fazer valer o mínimo de direitos que a lei, apesar de oscilante, lhes garantia e fizeram isso até o século XIX, contribuindo para impor limites à exploração do trabalhos indígena. ${ }^{39}$

As obrigações dos aldeados incluíam as mais diversas atividades, porém deviam prioritariamente atender aos serviços do rei, sobretudo os de defesa. Seu emprego nas obras públicas concentrou-se principalmente na construção e manutenção das fortalezas. Segundo o padre Plácido Nunes “[...] todas as Fortalezas, que se acham no Rio de Janeiro [...] foram feitas pelos Índios de Cabo Frio e S. Barnabé e outras Aldeias...". $4^{0}$ A aldeia de São Francisco Xavier de Itinga, dois anos depois de estabelecida, já "[...] podia dar 43 carijós, homens válidos para as obras da defesa do Rio". ${ }^{41}$ Em 1646, o governador Duarte Correa Vasqueanes referindose ao péssimo estado das fortificações ressaltava a necessidade de "[... ] trazer nelas todos os oficiais e índios que são necessários". ${ }^{22}$ Os aldeados constituíam também importante força militar na cidade, como demonstram vários documen-

39 ALMEIDA. Metamorfoses indígenas.

40 LEITE, Serafim. História da Companhia de Jesus no Brasil. Lisboa/Rio de Janeiro: Portugália/Civilização Brasileira, 1938-1950, v.VI, p. 129.

41 LEITE. História da Companhia de Jesus no Brasil, p.115.

42 Ms. Arquivo Histórico Ultramarino (AHU) Rio de Janeiro, documentos catalogados por CASTRO E ALMEIDA (RJCA) doc.438-439. 
tos, principalmente dos jesuítas frequentemente chamados para, com seus índios, acudir à defesa da cidade. ${ }^{43}$

Além das fortalezas, outras obras públicas ocupavam os índios: construíram o aqueduto da Carioca, abriram o Caminho Grande do Rio de Janeiro para Minas até o Rio Paraibuna, foram carregadores, extraíram pedras, cortaram madeiras, tanto para o serviço público como particular, foram remeiros, guias, flecheiros e caçadores de expedições dos sertões, perseguiram escravos negros fugitivos e atacaram quilombos, dentre muitas outras atividades. Para o serviço dos moradores, deviam ser recrutados principalmente para as lavouras, pastagens e expedições ao sertão, mas também cortavam madeiras, eram carregadores e faziam serviços domésticos. ${ }^{44}$

As ordens religiosas também se serviram largamente do trabalho dos índios em suas fazendas e residências, principalmente beneditinos e jesuítas, dos quais se tem mais informações. É instigante constatar, pelo menos duas ocasiões, nas quais os índios da aldeia de São Pedro parecem ter servido aos jesuítas também como uma espécie de exército particular. Afinal, combater era, pelo visto, a especialidade desses índios e os padres não deixaram de aproveitá-la. Por ocasião do litígio de terras entre os jesuítas e os padres de São Bento, na região de Cabo Frio, os índios atacaram e destruíram fazendas e currais dos beneditinos. No século XVIII, quando os inacianos se indispuseram com o administrador da armação de baleias na Ponta de Búzios, ameaçaram-no dizendo que os índios dali o expulsariam. Quanto aos padres de São Bento, documentos de sua própria ordem informam, como visto, a existência de índios administrados e escravos a seu serviço. ${ }^{45}$

A importância e a intensidade do trabalho dos aldeados na capitania variaram conforme tempos e espaços. No vale do Paraíba, tanto na região norte quanto sul, quando as últimas aldeias eram estabelecidas, no final do século XVIII e início do XIX, a mão de obra indígena ainda era bastante cobiçada. Além de apaziguar áreas, as novas aldeias davam aos moradores o acesso ao trabalho dos índios em seus pastos e lavouras, bem como nos cortes de madeira, serviço no qual os índios daquela região foram amplamente empregados. O caso do fazendeiro José Rodrigues da Cruz que atraiu os índios coroados para suas terras, tendo sido depois encarregado pela própria Coroa de aldeá-los, é bastante significativo sobre o interesse que o trabalho dos índios ainda despertava na região. ${ }^{46} \mathrm{Ali}$, foi bastante frequente, por parte de autoridades civis e eclesiásticas, distribuir os índios para serem apadrinhados por fazendeiros que os estabeleciam em suas próprias terras. ${ }^{47}$

O trabalho compulsório dos aldeados era obrigatório, mas tinha limites estabelecidos pela lei e pela resistência dos índios com forte apoio dos jesuítas até sua expulsão. A repartição do trabalho dos índios foi sempre problemática e gerou muitas disputas sobre as leis e seu cumprimento. ${ }^{48}$ Autoridades e padres preocu-

43 LEITE, História da Companhia de Jesus no Brasil, v. VI, pp.103-104.

44 ALMEIDA. Metamorfoses indígenas.

45 Ms. Arquivo do Mosteiro de São Bento do Rio de Janeiro. Estados do Mosteiro: Rio de Janeiro v. I e II: 16231793.

46 Sobre isso ver SILVA, Joaquim Norberto de Sousa. "Memória Histórica e Documentada das aldeias de índios do Rio de Janeiro". Revista do Instituto Histórico e Geográfico do Brasil. Rio de Janeiro. v. 62, n. 14, 1854, p.503-509; LEMOS, Marcelo. O Índio virou pó de café? - A resistência dos Índios Coroados de Valença frente à expansão cafeeira no Vale do Paraíba (1788-1836). Dissertação de Mestrado. Rio de Janeiro: UERJ, 2004; ALMEIDA, M Regina Celestino de. Almeida. "Os índios no tempo da Corte. Reflexões sobre política indigenista e cultura política indígena no Rio de Janeiro Oitocentista”. Revista USP, v. n. pp. 94-105.

47 MALHEIROS, Márcia. Homens de Fronteiras: índios e capuchinhos na ocupação dos sertões do leste do Paraíba ou Goytacazes. Tese de Doutorado. Niterói: UFF, 2007.; LEMOS. O Índio virou pó de café?.

48 Algumas leis trataram mais diretamente da repartição do trabalho dos índios aldeados, tais como a lei de 
pavam-se em manter um número mínimo de índios nas aldeias para assegurar sua manutenção e o atendimento aos serviços do rei. Para isso, as leis previam sistema de rodízio dos aldeados, limitando seu tempo máximo de trabalho fora das aldeias. Porém, as inúmeras leis faziam-se e cumpriam-se, no cotidiano da colônia, conforme as necessidades e pressão dos interessados e das conjunturas políticas e econômicas que levavam a Coroa a favorecer ou dificultar o acesso dos colonos aos trabalhadores indígenas.

Houve, por vezes, ordens para que os padres dessem todos os índios necessários ao serviço de autoridades, dos moradores ou da Coroa, o que nem sempre foi cumprido. Em outras ocasiões, por necessidades do serviço do rei ou pelo esvaziamento das aldeias, foi ordenado o retorno imediato de todos os índios às aldeias. Eram também frequentes as denúncias dos padres contra colonos e autoridades que retiravam das aldeias mais índios do que o permitido, desrespeitando o sistema de rodízio e o tempo máximo para a sua ausência. Em 1682, o reitor e outros padres da Cia. queixavam-se pela quantidade de índios e índias que ausentavam-se das aldeias de Itinga, São Barnabé e Cabo Frio por mais de dois meses, tempo destinado por Sua Majestade para servirem aos moradores. ${ }^{49}$ Mais de um bando foi proclamado ordenando a restituição dos índios, bandos esses provavelmente não cumpridos. Convém ressaltar, no entanto, que os índios podiam ficar nas fazendas e engenhos por vontade própria, como costumava ocorrer com os de São Barnabé que, atraídos pela liberdade dos costumes, não regressavam, segundo reclamação dos jesuítas. A prática de casar índios com escravos para impedir seu retorno às aldeias devia ser frequente, conforme muitas denúncias, que chegaram a incluir os próprios jesuítas..$^{50}$

A principal acusação contra os inacianos, feita tanto por moradores quanto por autoridades locais, era a de não distribuírem adequadamente os índios das aldeias para o trabalho compulsório, visando mantê-los para uso próprio e exclusivo em suas propriedades. As autoridades da colônia não tinham o direito de repartir os índios devendo recorrer, como os moradores, às aldeias em caso de necessidade; daí somarem suas reclamações às dos colonos contra os limites, segundo eles, impostos pelos jesuítas. Em 1645, o governador Francisco Soutomaior queixava-se dos padres da Companhia retirarem os índios dos serviços públicos da cidade. ${ }^{51}$

1680 (ampla lei de liberdade dos índios que proibira a escravização indígena em quaisquer circunstâncias), o Regimento das Missões de 1686 e o Diretório de 1757 . A Lei de 1680 introduzia “... a repartição tripartite dos índios alocados ao trabalho: uma para os serviços da própria aldeia, outra para servir aos moradores e uma terceira para acompanhar os missionários às missões" (BEOZZO. Leis e Regimentos das Missões, p.106). Tal lei, no entanto, pouco vigorou, dada a forte reação dos colonos contra os jesuítas em São Luiz e Belém, de onde foram expulsos. O Regimento das Missões, embora fortemente influenciado pelo padre Antonio Vieira, fez concessões aos moradores, como por exemplo, a divisão dos índios em duas partes, ao invés de três, para a repartição do trabalho, o aumento do tempo que podiam permanecer fora da aldeia e o pagamento antecipado de apenas metade do salário que, de acordo com a Lei de 1680, devia ser pago integralmente. Esse regimento vigorou até o estabelecimento do Diretório dos Índios de 1757. Esta lei, apesar de ter introduzido mudanças significativas na política indigenista, manteve as diretrizes básicas de 1686, no que se refere à repartição dos índios para o trabalho. A preocupação em assegurar o funcionamento da aldeia e o serviço do rei mantinha-se conforme o $\S 63$, no qual lê-se que "[... ] dividindose os ditos Indios em duas partes iguais, uma delas se conserve sempre nas suas povoações, assim para a defesa do Estado, como para todas as diligências do seu real serviço, e outra para se repartir aos moradores [...]" (Diretorio In: MOREIRA NETO, C. de A. Índios da Amazônia. De maioria a minoria (1750-1850). Rio de Janeiro: Vozes, 1988,p.192) O Regimento das Missões e o Diretório, embora elaborados inicialmente para a Amazônia, foram aplicados nas demais regiões, com as devidas adaptações. Para uma visão mais detalhada sobre as várias leis e suas determinações, ver BEOZZO. Leis e Regimentos das Missões, p.106-113; PERRONE-MOISES. "Índios livres e índios escravos".

49 Ms. Arquivo Nacional (ANRJ), cód. 77, vol.1, fl. 79v.

50 AZEVEDO, João Lucio de. Os Jesuítas no Grão-Pará. Lisboa: Tavares Cardoso \& Irmãos, 1991.

51 Ms. AHU, Rio de Janeiro, documentos avulsos (RJA), cx. 2, doc.57. 
Foi nessa mesma carta que o governador censurou o Principal da aldeia de Mangaratiba que lhe recusara os índios solicitados, alegando só obedecer ao general Salvador Correia de Sá.

Além de apontar para uma provável administração particular nessa aldeia, a acusação do governador contra o principal pressupõe a participação ativa dos índios nas decisões sobre seu trabalho fora das aldeias. Os embates eram, pois, frequentes e complexos envolvendo vários atores, dentre os quais os índios. A repartição dos aldeados para o trabalho ficava a cargo dos líderes indígenas que haviam se tornado capitães mores das aldeias e eram encarregados pela lei de intermediá-la, junto com o padre superior. Esta era uma das novas funções exercidas pelos principais na condição de capitães-mores das aldeias. Os jesuítas, inúmeras vezes, deixaram claro os limites de seu controle sobre os índios. Em situações de confronto, defendiam-se, alegando que os próprios índios se negavam a trabalhar.

O padre superior da aldeia de São Pedro, justificando o não cumprimento das ordens do rei para que os índios trabalhassem para os moradores de Cabo Frio, em 1683, dizia não poder obrigá-los “[... ]e que Vossa Majestade se cansará de lhe pedir rapazes e índios quando isso pertence ao Capitão dessa Aldeia para os nomear e irem então ao meu beneplácito". ${ }^{22}$ Trata-se de instigante embate entre a Câmara de Cabo Frio e os moradores contra os jesuítas acusados de enviar os índios para servirem a seus amigos no Rio de Janeiro, deixando os pobres moradores desprovidos de trabalhadores. A ordem do rei favorável aos primeiros não foi cumprida e os padres alegaram nada poder fazer contra a vontade daqueles índios que eram muitos e fortemente unidos entre si. Segundo eles, os índios afirmavam seu interesse em trabalhar no Rio porque lá recebiam mais e em dinheiro, enquanto, em Cabo Frio, eram pagos com panos de algodão.

Outro exemplo sobre a vontade e decisão dos índios quanto aos serviços prestados fora da aldeia nos é dado pelo padre Francisco Morais que ressaltou o “[... ] notável desaforo em que estão com não quererem ir servir senão os que eles querem e pelo preço que eles querem, e se os obrigamos, ausentam-se da Aldeia ...". ${ }^{3} \mathrm{Em}$ 1795, Manoel M. do Couto Reys, administrador da Fazenda de Santa Cruz referindo-se ao trabalho dos índios, afirmava que "quem os nomeia, quem os atende nas representações é o seu capitão mor...".54

Cabe, porém, ressaltar que esses chefes indígenas, feitos capitães-mores das aldeias e encarregados de repartir os índios para o trabalho, também enfrentavam resistência por parte de seus subordinados. Em Itaguaí, no início do século XIX, o capitão-mor dizia ser dificil arregimentar os índios para os serviços do rei, pois muitos refugiavam-se para dele escapar e os solteiros iam para a pesca e não voltavam. ${ }^{55}$ Com certeza, havia nas aldeias um complexo jogo de forças entre os chefes indígenas, os índios comuns, os padres superiores, os moradores e as autoridades locais. Sem descartar as possíveis dissimulações presentes em todos esses discursos que procuravam justificar o não cumprimento das ordens, é imperioso constatar a participação dos líderes indígenas nesses embates.

O trabalho fora das aldeias devia ser remunerado e, embora muito mal pago, despertava o interesse dos índios. Por mais irrisórios que fossem seus salários, em várias ocasiões, eles se manifestaram procurando garanti-los ou aumentá-los. $\mathrm{O}$ dinheiro era parte do mundo colonial e os índios aprenderam a fazer uso dele e a

52 Ms. AHU RJA, Cx. 5, doc. 45 .

53 LEITE, Serafim, op. cit. p. 98.

54 Ms.ANRJ, Fazenda de Santa Cruz, caixa 507, pacote 1.

55 SILVA, Joaquim Norberto de Sousa, op. cit.pp.373-374. 
reivindicá-lo. Os capitães-mores das aldeias, cujos cargos nem sempre eram remunerados, buscavam através de recursos jurídicos obter soldos que consideravam justos para o exercício de suas funções lançando mão, em geral, de exemplos de seus pares que recebiam salários. Várias solicitações por parte de líderes indígenas demandavam aumento do soldo e de ajudas de custo necessários, segundo eles, para o bom cumprimento do serviço de Sua Majestade.

O pagamento dos serviços dos índios aldeados fora das aldeias era variado podendo ser em espécie, principalmente rolos de algodão, ou em dinheiro. Há alguns registros interessantes sobre embates em torno de seu pagamento, como no já citado caso de Cabo Frio. Dentre outros exemplos, cabe destacar a reivindicação de Miguel Duarte, índio do Cabelo Corredio. Ele se apresentava, em 1741, como "procurador de todos os mais índios aldeados no distrito da Capitania do Rio de Janeiro e das mais capitanias anexas aquele Governo...". Solicitava aumento de soldo, argumentando que “... como leais vassalos de V.M. estão sempre prontos para o seu real serviço, tanto nas obras que se fazem na cidade, como pelas mais capitanias...". ${ }^{56}$ Referia-se aos exaustivos serviços prestados com prejuízo de suas mulheres e filhos que ficavam na aldeia sem ter quem os sustentassem. O parecer do Conselho Ultramarino Ihe foi favorável.

Este requerimento é especialmente instigante porque revela uma identificação dos aldeados num âmbito que vai além das aldeias. Trata-se de uma ação coletiva encaminhada por um índio que se assumia como representante de índios de diferentes aldeias identificados entre si por serem aldeados, trabalharem para os serviços do rei e serem mal pagos. Este exemplo não deixa dúvidas sobre o envolvimento dos índios nas disputas referentes aos seus trabalhos e salários, revelando sua consciência sobre a condição específica por eles ocupada no mundo colonial e do papel que ali desempenhavam. De acordo com as reivindicações, sabiam o seu lugar: eram subordinados, mas tinham um papel a desempenhar na colônia, servindo ao rei e, pelo bom desempenho desse papel, mereciam mercês e as reivindicavam conforme os códigos portugueses.

A partir do século XVIII, o trabalho dos aldeados deve ter superado em larga escala o dos escravos índios, e devia ser mais amplamente empregado nos serviços públicos, na medida em que os escravos negros iam se tornando mais acessíveis aos colonos. A documentação sobre conflitos nas aldeias revela que, desde meados do setecentos, as disputas nas antigas aldeias coloniais se faziam mais por questões de terra do que pelo trabalho dos índios. Isso pode indicar uma diminuição do interesse dos colonos na mão de obra indígena, se comparada com períodos anteriores..$^{57}$

Cabe, no entanto, considerar que a diminuição do uso da força de trabalho indígena na capitania não significou absolutamente seu desaparecimento total, visto que continuaram servindo aos moradores e principalmente à Coroa até o século XIX, como visto anteriormente. Trata-se, portanto, do esgotamento das possibilidades de sua utilização em larga escala que, nos primeiros séculos da colonização, devia se dar principalmente através das escravizações maciças propiciadas pelas guerras contra os gentios e por expedições de resgate. Essas expedições, não resta dúvida, foram diminuindo nos arredores da cidade na medida em que a colonização avançava. Embora os escravos índios viessem também de regiões mais distantes, sendo introduzidos, sobretudo, pelos paulistas, a tendên-

56 Ms. AHU RJCA cx. 48, doc. 11346.

57 Sobre isso ver ALMEIDA. Metamorfoses indígenas. 
cia era igualmente para a sua diminuição. Convém ainda considerar que os índios das aldeias mais próximas à cidade também sofreram uma redução considerável nos dois primeiros séculos da colonização e isso, sem dúvida, afetava o mercado de trabalho.

\section{Considerações finais}

Na condição de aldeados ou de escravos, os índios constituíram importante força de trabalho na capitania do Rio de Janeiro durante o século XVII. No decorrer do século XVIII e início do XIX, a escravização indígena não desapareceu, mas deve ter recuado bastante, face aos vários fatores acima citados. A partir de meados do século XVIII deve ter se tornado bem mais rarefeita, com a lei de 1755 que proibia a escravização indígena sob quaisquer circunstâncias. $O$ trabalho compulsório dos índios, no entanto, iria permanecer legalizado até o império, em diferentes modalidades e mediado pelas disputas dos agentes envolvidos.

Tal como em outras regiões da América, a mão de obra indígena foi básica no Rio de Janeiro, sobretudo nos primeiros séculos da colonização, tendo declinado por várias razões. A diminuição das possibilidades de sua utilização caminhou junto com o desenvolvimento cada vez maior do mercado de escravos africanos na capitania. 
